\title{
Regional anti-corruption effort, political connections and firm innovation effort: Evidence from China
}

\begin{abstract}
This paper examines how firm characteristics and local anti-corruption effort moderate the influence of political connections on enterprises' private R\&D investment using data from 2,587 Chinese A-share listed enterprises. Our results show that the local anti-corruption institutional environment significantly moderates the strong relationship between political connections and enterprises' private R\&D investment. Firm characteristics (i.e., firm size and firm age) also show a moderating effect on the relationship between political connection and enterprises' private R\&D investment; larger and older enterprises are more likely to have innovative resources and business cooperation partners, and thus are able to reduce their degree of reliance on political connections and government funding. The results of this study suggest that the availability of a transparent and fair institutional environment for enterprise innovation activities is indispensable.
\end{abstract}

Keywords: Political connections; enterprise R\&D investment; local anti-corruption; firm age; firm size; China.

JEL: G38; N45; L26; L25

\section{Introduction}

Political connections, which are viewed as one type of valuable resource, play a crucial role in helping enterprises to obtain considerable funding (e.g., tax exemptions, funding support, project subsidies, interest-free loans, or discounted government loans) (Faccio, 2010; Bayraktar \& Moreno-Dodson, 2015). Political connections also help to 
alleviate enterprises' financial constraints, especially in an incomplete or less developed market with a lack of mature legal infrastructure (e.g., Yen et al. 2014; Cull et al., 2015; Zhou, 2013; Li et al., 2008; Cai and Li, 2014; Walder, 2002). The relationship between political connections and $R \& D$ activities has been broadly examined in prior studies, but the results are inconsistent and varying. Previous studies have found a positive effect of political connections on R\&D (Khwaja and Mian, 2005, Johnson and Mitton, 2003; and Faccio, 2006), a negative impact of political connections on R\&D (Jackowicz et al., 2014; Lin et al., 2014; Luo, 2008; Wang and Chung, 2013; Fan et al., 2007), and an inverted U-shaped relationship, whereby the positive effect of political ties on product innovation gradually increases with the costs of establishing political ties, and then decreases again above a certain threshold (Wu, 2011, Song et al., 2015).

The inconsistent positive effect of political connections on enterprises' R\&D investment may be attributed to the fact that prior studies did not take into consideration the influence of external factors (e.g., legal environment) and firm characteristics (e.g., firm types, age and size) on innovation outputs (Jiao et al., 2015; Allred and Park, 2007; Qian, 2007; Anokhin and Schulze, 2009). This is the principal focus of our study. In this research, we model anti-corruption effort as a moderating variable, and examine how the establishment of anti-corruption institutions can adjust the positive effect of political connections on enterprises' $R \& D$ input. The institutional environment in a transition economy with low rent-seeking costs may lead to strong political connections (Shleifer \& Vishn, 1994; Al-Azzam, 2016). Cumulative abnormal return (CAR) refers the difference between the expected return on a stock and the actual return. Prior studies propose that political ties usually generate a statistically significant cumulative abnormal return (CAR) of $4.32 \%$ in a 
country with high-level corruption, but the value of CAR will be reduced to a negative impact $(-0.02 \%)$ in countries with low-level corruption (Faccio, et al., 2006). However, in the world's least corrupt country, Denmark (Barfort, et al., 2015), political connections still exert a significant positive effect on firms' performance (Amore and Bennedsen, 2013). Anti-corruption effort may therefore moderate the positive effect of political connections on enterprises' R\&D input.

Firm characteristics should also moderate the relationship between a firm's political connections and its $R \& D$ input. We argue that the effect of government funding on a firm's innovation activities should vary with the growth of the firm. Although a large and mature firm is more likely to obtain state funding, we expect that the relationship between political connections and private $R \& D$ investment will be weakened. We further examine the moderating effect of two firm characteristics firm size and age - on the above relationship.

This study contributes to the literature on political connections in several important ways. First, this study is the first to explore how the strength of ties with government or politicians relates to firms' innovation effort. We provide empirical evidence to explain the inconsistent findings on the precise role of political ties on firms' private R\&D investment. Second, our findings extend the literature to consider the impact of external contextual factors (local anti-corruption effort) on the relationship between a firm's political connections and its innovation effort. Following previous studies examining the different effects of political ties in countries or regions with different levels of corruption, our study empirically investigates how different local anti-corruption policies can moderate the relationship between political connections and enterprises' R\&D investment in China, where an anti- corruption campaign is currently being implemented. President Xi launched a far-reaching 
campaign against corruption in China following the conclusion of the 18th National Congress of the Communist Party in 2012. Most of the officials investigated were removed from office and faced accusations of bribery and abuse of power (ChinaPower, 2013). Thus, we used the two-year event window to measure the moderating effect of anti-corruption activities. The anti-corruption campaign created an ideal empirical setting for us to examine the moderating effect of local anti-corruption activities. Our findings may contribute to helping governments in transitional economies to improve their current legal institutions and then to decrease politicians' rent-seeking behavior. Third, we contribute to examining the moderating effects of the influence of inner contextual factors (firm age and size) on the relationship between political connection and enterprises' R\&D investment, using data collected from Chinese firms with different characteristics. These additional results serve as a justification of the unstable effect of political connection identified by prior studies.

The remainder of our paper is organized as follows. The next section describes the theoretical background of the study and introduces hypotheses. This is followed by a section discussing the research methods used in the study. The empirical results are provided in Section four. Finally, the last section discusses the practical and theoretical contribution of the study, along with limitations and directions for future research.

\section{Literature Review and Hypothesis Development}

\subsection{The effect of political connections on enterprises'innovation activities}

The complex, uncertain and risky nature of enterprises' innovation activities makes $\mathrm{R} \& \mathrm{D}$ investment an unstable approach for yielding the expected innovation outputs 
(e.g., new products) in a given period (Lin et al., 2011).

From the resource-based view (RBV) (Barney, 1991; Conner, 1991; Penrose, 1959; Wernerfelt, 1984), enterprises with strong political connections may receive priority channels for obtaining government resources and funding support to alleviate their financial constraints (Cull et al., 2015). Developing political connections may enable firms to better understand the unwritten rules of funding allocation and to achieve a competitive advantage. Existing studies suggest that political connections exert a positive effect on firms' innovation capabilities and innovation outputs (e.g., Wu, 2011; Shi and Zhu, 2014). For instance, Wu (2011) conducted an extensive survey of 766 Chinese firms and found that the relationship between political ties and product innovation is an inverted U-shape, indicating that the positive effect of political ties on product innovation diminishes as the costs of political ties begin to outweigh the benefits. Shi and Zhu (2014) empirically examine the relationship between political connections and technology innovation outputs through a sample of 243 listed firms in the information technology industry and 120 listed firms in the pharmaceutical industry in China and show that political connections have a positive impact on a firm's technology innovation outputs.

Conversely, using a theoretical framework combining stakeholder theory with the resource-based view (RBV), Lin et al. (2014) investigate the effects of firms' political capital on firm innovation via a survey of 791 private manufacturing firms in China. Their study however reveal a negative relationship between the two variables. Wang and Chung (2013) used a sample of 420 firms from key industrial sectors listed in the Taiwan Yellow Pages and the Taiwan Stock Exchange listings. A survey was delivered to CEOs and senior managers. Based on 122 valid firm responses, they argue that some firms with strong political connections may receive government 
favoritism but still lack innovation capabilities. One plausible explanation is that strong political ties impede a firm's innovation activities and development. First, from the knowledge management perspective, the organizational culture regarding knowledge management processes for a firm with strong political connections usually tends to be more hierarchical than that of a firm with poor political connections. A hierarchical corporate culture will significantly reduce a firm's intrinsic motivation toward strengthening product innovation, thus leading to a negative impact on knowledge coordination and integration and innovation activities (Sethi et al., 2001). A firm's high-level political connections may also be harmful for the implementation of the firm's customer orientation and market-stimulated innovation strategies (Luo, 2008). This may lead to an infant industry dilemma, whereby firms are assisted by subsidies or other forms of government resources, but end up being unsustainable and more importantly unable to cultivate innovation capability and become internationally competitive (Saure, 2007; Melitz, 2005).

Thus, we propose the following competing hypotheses:

Hla: Political connections exert a positive effect on enterprises' private $R \& D$ investment.

HIb: Political connections exert a negative effect on enterprises' private $R \& D$ investment.

H1c: Political connections exert little effect on enterprises' private $R \& D$ investment.

Following prior studies, we propose that the impact of political connections on $R \& D$ investment is not independent from firms' characteristics and their external context (e.g., local legal enforcement). Thus, it is imperative to investigate how political connections provide varying effects on $R \& D$ under different conditions. A better 
understanding of the moderating effect of firms' characteristics and institutional context is essential to inform government on how to more cost-effectively allocate resources, and thereby optimize subsidy strategies.

\subsection{The moderating effects of firm characteristics}

Prior studies have suggested that firm characteristics sometimes significantly adjust the positive relationship between a firm's input efforts and output findings: examples include the relationship between technology investments and high-growth profitability (Wöhrl et al., 2009), and the relationship between external technology acquisition and product innovativeness (Tsai et al., 2011). In addition, firm size is one of the most commonly studied organizational factors in the innovation literature (Damanpour, 1992). For example, compared with small and medium-sized enterprises (SMEs), large-scale firms have more financial and technical capabilities and are more active at leveraging external resources for developing innovative research projects (Dooley et al., 2015; Chandy and Tellis, 2000; Hitt et al., 1991; Wakasugi and Koyata 1997). $\mathrm{R} \& \mathrm{D}$ is typically associated with uncertainty and risk, and large-scale firms usually have accumulated considerable practical experience and resources for risk management to gradually transfer novel business ideas into innovative products (Ettlie and Rubenstein, 1987; Golovko and Valentini, 2014). Small firms show a higher dependence on obtaining government funding through private political connections due to limited external resources and technical advantages (Prajogo et al., 2013; Zhou, 2013). We argue that large, mature firms will have established more business cooperation partners and will therefore be able to use these connections to obtain more non-government resources for their $R \& D$. Thus, we posit the following hypotheses: 
H2: Firm age negatively moderates the relationship between political connections and enterprises 'private $R \& D$ investment.

H3: Firm size negatively moderates the relationship between political connections and enterprises 'private $R \& D$ investment.

\subsection{The moderating effects of the degree of local anti-corruption effort}

In some countries that lack poor legal enforcement, company managers may develop unlawful personal connections. Such personal connections represent a closet relationship, which may be a key ingredient in helping firms to obtain external resources. For instance, developing a solid personal relationship (i.e., "Guanxi”) with government officers in China is critical to secure government subsidies. Guanxi enables these companies to quickly obtain important information regarding government subsides, including the review criteria and application procedures. However, such personal relationships increase company managers' intentions to carry out rent-seeking behaviors, due to a lack of legal enforcement. Consequently, public officials offer special services to select private firms in order to obtain personal benefits, violating the law and their duties.

Xin and Pearce (1996) argue that "Guanxi” can be used as a substitute for formal institutional support in China. Government officials may secretly provide important funding information to company leaders. Corrupt companies could unlawfully obtain considerable government funding for their R\&D development (Yu and Pan, 2008). We argue that such "rent-seeking" behavior will be significantly inhibited by the implementation of anti-corruption campaigns. As a result, government officers are unlikely to offer illegitimate support to companies even if the company leaders have a strong relationship with them. In other words, the role of political connections in 
helping companies to obtain government subsidies for R\&D development will be decreased. Zhou (2014) found that the role of political connections significantly declines as the Chinese government pays more attention to implementing institutional reforms and law enforcement. Thus, we propose that anti-corruption campaigns will moderate the influence of political connections (i.e. their importance in determining $\mathrm{R} \& \mathrm{D}$ investment will decrease as an anti-corruption campaign deepens). Drawing on this logic we predict:

H4: The strength of an anti-corruption campaign negatively moderates the relationship between political connections and enterprises'private $R \& D$ investment.

\section{Research methods}

\subsection{Sample}

In this study, the research hypotheses are empirically examined in China. Firms in China are more likely to establish personal political connections to better understand the mechanisms of funding allocation in China - these are somewhat less transparent and market-oriented compared to Western countries (Chen and $\mathrm{Wu}, 2011$ ). The Chinese government has launched a series of severe anti-corruption campaigns since 2012, which have prosecuted over 100 high-ranking government officials. Such a national anti-corruption campaign is expected to create an ideal empirical setting for us to examine the moderating effect of local anti-corruption activities. Recent empirical findings show that, following the anti-corruption campaign and the development of regional anti-corruption institutions (e.g., the inner-party supervision institute and the institute for selecting and employing supervisory roles), political connections have a less significant role in helping enterprises to improve their innovation capabilities (Zhou, 2014). These unique anti-corruption institutions allow 
us to explore how the level of local anti-corruption effort moderates the relationship between political connections and enterprises' $R \& D$ investment, which contributes to a better understanding of the role of political connections in different legal contexts.

Data from 2,587 Chinese A-share listed enterprises (on the Shanghai and Shenzhen stock exchanges) were collected from 2012 to 2014, which includes information such as firm size, income and fixed assets. These firms are located in China's 21 provinces, 4 municipalities, or 5 autonomous regions, excluding the special administrative regions (i.e., Hong Kong and Macau). Overall, 12 industries are included in the sample: Industrial Manufacturing (35.433\%), IT (2.978\%), and Software and Information Technology Services (38.449\%) (See Table 1). The average number of employees in these firms is 5,681 and 50\% of firms have less than 1,570 employees. The average age of firms in the sample is 18.243 years (See Table 2).

To assess the degree of local anti-corruption effort, data were collected from two widely used databases in China: the Procuratorial Yearbook (2012-2014) and the China Statistical Yearbook (2012-2014). The former records the annual number of corruption and bribery cases in each province or municipality, while the latter collects the annual number of civil servants in each administrative division of China. We then average the number of corruption and bribery cases across the three-year period to measure the degree of local anti-corruption effort.

$$
\begin{aligned}
& * * * \text { INSERT TABLE } 1 \text { ABOUT HERE *** } \\
& * * * \text { INSERT TABLE } 2 \text { ABOUT HERE *** }
\end{aligned}
$$

\subsection{Measures}

The independent variable R\&Dinput was measured using the average share of enterprises' private $R \& D$ investment as a proportion of their annual revenues from 2012-2014. We define private R\&D investment as innovative ideas, information and 
other intangible elements (e.g., property rights) contributed by a firm's R\&D employees. However, since $R \&$ Dinput is hard to measure empirically because of its intangibility, we use private $R \& D$ investment as a proximate predictor of $R \& D$ input in this research. We argue that enterprises need to spend considerable funding on producing these intangible assets (e.g., novel business ideas), and thus private $R \& D$ investment may be viewed as an indicator of the relative strength of enterprises' $R \& D$ input.

PoliticalConnection was modeled as an independent variable in this research. Prior studies on revolving doors (e.g., Makkai and Braithwaite, 1992; Salant,1995) suggest a company manager is expected to utilize his or her former network of political relationships to help a company if they were employed previously as a civil servant or public servant. Following prior studies (e.g., Peng and Luo, 2000), we measure this variable by reviewing leadership team members' interpersonal relationships with Chinese government officials based on two steps. First, we used automated techniques for data collection and analysis. We developed a web crawler to collect relevant data from Eastmoney.com - a Chinese financial and stock information website. Our web crawler visits Eastmoney.com and automatically collects all the required information in the summary section of firms, including managers' personal experience. The information was downloaded and saved in CSV file format for further statistical analysis. Managers' profiles were collected at a disaggregate level (individual profiles) so that it was possible to parse individual profiles and aggregate them for our analysis. We examined whether or not individuals had previous work experience in any Chinese government sector. Second, a 5-point Likert scale with a score of 5 indicating 'the strongest political connections' and a score of 1 indicating 'the weakest political connections' was used. The score was rated based on company 
leaders' political rank in their past positions, such as national-level leaders, provincial-level officials, and prefecture-department officials. We calculate the "political connections" for a firm based on the total sum of all senior management team members' (e.g., president, vice president and CEO) scores for political connections. Three researchers were invited to rate the degree of political connections of company leaders respectively and inconsistency ratings were reviewed and a final score determined.

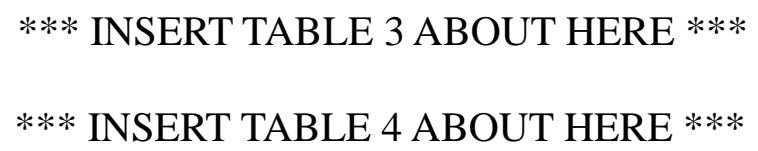

Three moderating variables are included in our model: Anticorrupt, Firmsize and Firmage. The variable Anticorrupt represents the annual average number of corruption and bribery cases per 10,000 civil servants in an administrative division between 2012 and 2014. We use the average total number of employees of a firm between 2012 and 2014 as Firmsize. The variable Firmage was measured by the time that a firm has been legally established.

Control variables may potentially influence the dependent variables in a research model (Doney and Cannon, 1997). To examine the influence of political connections on R\&D input and the moderating effect of the above three variables (i.e., Anticorrupt, Firmsize and Firmage ) on this relationship, this study controls for four factors. The variable GovSupport represents the average share of government subsidies in annual revenues for each enterprise from 2012-2014. Related data were collected from financial indicators listed in the annual reports of enterprises. Income refers to a firm's annual overall sales revenue. Topshare refers to the percentage of the shares of the largest shareholder of an enterprise; $R O A$ represents the return on assets of an enterprise, which includes the return on total assets, return on total core 
assets, return on net assets, and return on total net worth.

\section{Data analysis and results}

We use two sets of regression equations for the data analysis. Model A describes the relationship between political connections and $R \& D$ private investment for examining Hypothesis 1:

\section{Model A: $b_{0}+b_{1} * f($ PoliticalC onnection $)=R \&$ Dinput}

In addition to a linear equation, different functions representing the degree of political connections were used in Model A to investigate in detail the relationship between the independent and dependent variables (see Table 5).

\section{*** INSERT TABLE 5 ABOUT HERE ***}

The linear regression of Model A shows that there is a positive relationship between enterprises' political connections and R\&D private investment (H1 supported). As Table 5 illustrates, the linear equation offers the best result, while further sophistication via the quadratic and cubic equations do not increase the explanatory values $\left(\mathrm{R}^{2}\right)$ and significance. Moreover, following Anderson and Burnham (2002) and Akaike (1974), we calculate the AIC (Akaike Information Criterion), which adjusts each model's likelihood to take the number of parameters into account. We compute this criterion for each model, then choose the model with the smallest AIC (i.e. the linear model). We also consider other indices, such as RMSE. Lower values of RMSE indicate better fit. RMSE is a good measure of how accurately the model predicts the response, and is the most important criterion for fit 
if the main purpose of the model is prediction. The linear model based on our dataset has the lowest value. Therefore, we will use a linear regression model to estimate the relationships between multi-variables.

To examine the moderating effects of firm age, size and the degree of anti-corruption effort (i.e., $\mathrm{H} 2, \mathrm{H} 3, \mathrm{H} 4$ and $\mathrm{H} 5$ ), a step-wise regression procedure was used to take into account firm age, firm size, and anti-corruption effort as interaction terms. The step-wise approach is increasingly used in multivariate statistics to enhance the explanatory power of regression analysis (Royston and Sauerbrei, 2008). In this approach, cross product terms (i.e., PoliticalConnection *Firmsize , PoliticalC onnection * Firmage , and PoliticalConnection *Anticorrupt ) were introduced, adding additional terms to the equations from step one to step two (Neter et al., 1990). We use an F-statistic to examine the moderating effects of firm age, size and the degree of anti-corruption effort. The results are statistically significant if the additionally explained variance $\left(\mathrm{R}^{2}\right)$ shows a substantial increase in the F-statistic (Hoffman et al., 1992).

The statistical models examined in our analysis are as follows:

Model 1a:

$$
b_{0}+a_{0} * \text { control }+b_{1} * \text { PoliticalC onnection }+b_{2} * \text { Firmage }=R \& \text { Dinput }
$$

Model 1b:

$$
\begin{aligned}
& b_{0}+a_{0} * \text { control }+b_{1} * \text { PoliticalC onnection }+b_{2} * \text { Firmage } \\
& +b_{3}(\text { PoliticalC onnection } * \text { Firmage })=R \& \text { Dinput }
\end{aligned}
$$

Model 2a:

$$
b_{0}+a_{0} * \text { control }+b_{1} * \text { PoliticalC onnection }+b_{2} * \text { Firmsize }=R \& \text { Dinput }
$$

Model 2b: 


$$
\begin{aligned}
& b_{0}+a_{0} * \text { control }+b_{1} * \text { PoliticalC onnection }+b_{2} * \text { Firmsize } \\
& +b_{3}(\text { PoliticalC onnection } * \text { Firmsize })=R \& \text { Dinput }
\end{aligned}
$$

Model 3a:

$$
b_{0}+a_{0} * \text { control }+b_{1} * \text { PoliticalC onnection }+b_{2} * \text { Anticorrupt }=R \& \text { Dinput }
$$

Model 3b:

$$
\begin{aligned}
& b_{0}+a_{0} * \text { control }+b_{1} * \text { PoliticalC onnection }+b_{2} * \text { Anticorrupt } \\
& +b_{3}(\text { PoliticalC onnection } * \text { Anticorrupt })=R \& \text { Dinput }
\end{aligned}
$$

The results of the estimations of the linear models are presented in Table 6. For the dependent variable in each model, three different models were estimated. First, models with only control variables were estimated (see Model 0 in Table 6). This model serves as a baseline model. The three moderating variables Anticorrupt, Firmsize and Firmage respectively were added to the baseline model. Our research findings show that the baseline model was highly significant and had a relatively high explanatory power $(28.9 \%)$.

\section{*** INSERT TABLE 6 ABOUT HERE ***}

Table 6 summarizes the moderating effect of firm size on the relationship between political connections and enterprise $R \& D$ investment. The value of $R^{2}$ in model 1 increased to $37.3 \%$ when the moderating variable was introduced. The results presented in Model 1 show a negative interaction effect of firm size on the influence of political connection $\left(b_{3}=-0.209, p<0.01\right)$ on enterprise $R \& D$ investment $(H 3$ supported).

Table 6 also presents the moderating effect of firm age on the relationship 
between political connections and enterprise $R \& D$ investment. The value of $R^{2}$ in Model 2 increased to $31.8 \%$ when the moderating variable was introduced. The results presented in Model 2 show a negative interaction effect of firm age on the relationship between political connections and enterprises'private $R \& D$ investment $\left(\mathrm{b}_{4}=-0.129, \mathrm{p}<0.01\right)$ (H2 supported). Our empirical findings show that large-scale enterprises will have more innovative resources to utilize, thereby reducing their reliance on political resources as compared to SMEs.

To examine how the degree of local anti-corruption effort moderates the positive effect of political connections on enterprise $R \& D$ investment, we further introduce the interaction term PoliticalConnection*Anticorrupt into Model 3b. Our findings show that the degree of local anti-corruption effort has a moderating effect on the relationship between political connection and enterprise R\&D investment at the $10 \%$ level of significance $(\mathrm{b} 5=-.026, \mathrm{p}<0.1)(\mathrm{H} 4$ supported $)$.

\section{Discussion and Conclusions}

This study has investigated the role of political connections in motivating enterprises' private $\mathrm{R} \& \mathrm{D}$ investment, including an examination of the moderating effects of firm age, firm size and the degree of local anti-corruption effort on this relationship.

We find that political connections do positively influence a firm's R\&D investment, rather than hinder innovation activities. Most of prior studies are conducted based on a relatively small sample or based on one or two industries. Instances of such work include that of Wu (2011), who investigated 766 firms in five manufacturing sectors, Shi and Zhu (2014), who empirically test the influence of political connections on R\&D through a sample of 243 listed firms in the information 
technology industry and 120 listed firms in the pharmaceutical industry in China, Lin et al. (2014), who use a survey of 791 private manufacturing firms in China, and Wang and Chung (2013), who identified 420 firms from key industrial sectors in Taiwan. This research developed a web crawler to automatically extract information about all public companies trading on the two Chinese stock exchanges, that is, the Shanghai Stock Exchange and the Shenzhen Stock Exchange. Thus, our empirical findings should be more reliable for generalization (i.e., have external validity) due to a large sample across different regions and 13 industries. The main effect of political connections on firm innovation $\left(b_{1}=0.145\right)$ that we found in this paper was consistent with the results of $\mathrm{Wu}(2011)\left(\mathrm{b}_{1}=0.02\right)$ and Shu et al. (2012) $\left(\mathrm{b}_{1}=2.33\right)$.

By being connected to government officials, firms are able to identify potential funding sources and to quickly understand the application procedures to be able to secure the R\&D subsidies available. China's business relationships are highly socially embedded and so the social capital within these political connections is advantageous to the firm's ability to invest in R\&D activities within this political context. Political connections may buffer firms from financial pressures and act as a helping hand for enterprises to gain more government subsidies for risky and uncertainty innovation activities.

Our research findings show that firm characteristics (i.e., size and age) significantly moderate the role of political connections on enterprises' $R \& D$ and innovation activities. Thus, it appears that the role of political resources in motivating an enterprise's innovation efforts will gradually decrease as the enterprise grows or matures. One plausible explanation for this finding is that a large or mature company is likely to have accumulated business resources and external partnerships, thus decreasing its dependence on government subsidies for R\&D. This suggests that it 
will be easier for large and more mature companies to gain substantive support from relationships with suppliers, universities, customers, and even competitors for their innovation efforts. Small and new firms are more dependent on government subsidies for their R\&D projects and innovation activities. The moderating role of local anti-corruption effort on the main effect suggests that institutional reforms and law enforcement will weaken the relationship between political connections and enterprises' $\mathrm{R} \& \mathrm{D}$ investment as a fair and transparent environment for enterprises is established. As a result, the rent-seeking behavior of government officials is significantly inhibited. Thus, enterprises should place an emphasis on strengthening sustainable innovation using other non-official financial resources, such as establishing cooperation with universities on emerging projects.

The practical implications of our findings are that government departments should consider offering specialized R\&D funding for new firms and SMEs to help them launch innovative activities. Startup companies should place more emphasis on developing sustained relationships with a diverse range of business partners to enable them to obtain valuable business resources and to reduce their reliance on government subsidies and funding. The moderating effect of anti-corruption campaigns provides an important tool for government: countries with transition economies should seek to increase the development of open and transparent government institutions and establish more objective mechanisms. This will reduce the reliance on political connections and reduce corruption within the institutional environment, providing a more level playing field for all firms.

This study is not without limitations. First, the study has been conducted within a single market context (i.e., Mainland China). To be able to generalize the findings to other countries would require that the specific characteristics of these countries are 
understood. Further research should replicate this study in different countries and political contexts. Second, we only focus on the political connections of firm leadership, and ignore other firm or management team characteristics, such as business ties, professional ties, industry experience, and board composition, which may also influence firms' innovation strategies (Yoo and Reed, 2015). Third, we sample a three year-period of data (i.e., 2012 to 2014) to calculate the level of local anti-corruption effort, thus limiting the delayed moderating effect of anti-corruption. This may help to explain why the moderating effect of anti-corruption effort is significant only at the $10 \%$ level. An ideal empirical design for testing fully the moderating effect of anti-corruption effort would be a longitudinal comparison of the role of political connections on $R \& D$ investment over time, and consequently, this is recommended as an avenue for future research.

\section{Acknowledgments}

This research is supported by Hohai University's Basic Scientific Research Fund for Central Colleges and Universities (Project no. 2016B09114) and the Ministry of Education's Humanities and Social Sciences Youth Research Fund (Project no. 16YJC630028). The authors thank the two anonymous BER reviewers and Associate Editor for comments that greatly improved the article. The authors thank Xiaotong Li for helpful comments.

\section{References}

Akaike, H. 1974. A new look at the statistical model identification. IEEE transactions on automatic control, 19(6), 716-723.

Al-Azzam, Moh. 2016.Corruption and microcredit interest rates: does regulation help? Bulletin of Economic Research, Version of Record online: 22 APR 2016. 
Allred B B, Park W G. 2007. The influence of patent protection on firm innovation investment in manufacturing industries. Journal of International Management, 13,2: 91-109.

Anderson, D. R., \& Burnham, K. P. 2002. Avoiding pitfalls when using information-theoretic methods. The Journal of Wildlife Management, 912-918.

Anokhin S, Schulze W S. 2009.Entrepreneurship, innovation, and corruption. Journal of Business Venturing, 24,5: 465-476.

Amore, Mario Daniele, and Morten Bennedsen, 2013. The value of local political connections in a low-corruption environment. Journal of Financial Economics, $110,2,387-402$.

Barfort S, et al.2015.Dishonesty and Selection into Public Service in Denmark: Who Runs the World's Least Corrupt Public Sector?. Available at SSRN 2664983.

Barker III, Vincent L., and George C. Mueller, 2002. CEO Characteristics and Firm R\&D Spending. Management Science, 48, 6,782-801.

Barney, Jay, 1991. Firm resources and sustained competitive advantage. Journal of management, 17, 1, 99-120.

Bayraktar, Nihal, and Blanca Moreno-Dodson. 2015. How can public spending help you grow? An empirical analysis for developing countries. Bulletin of Economic Research, 67,1,30-64.

Cai, Dapeng, and Li Jie. 2014. Subsidization and Bargaining in Mixed Oligopolies. Bulletin of Economic Research, 66,4,358-373.

ChinaPower 2013. Can Xi Jinping's anti-corruption campaign succeed? Available from:http://chinapower.csis.org/can-xi-jinpings-anti-corruption-campaign-succee d/

Conner, Kathleen R, 1991. A historical comparison of resource-based theory and five schools of thought within industrial organization economics: do we have a new theory of the firm? Journal of Management, 17, 1, 121-154. 
Chen, Xiaoyun, and Jie Wu, 2011. Do different guanxi types affect capability building differently? A contingency view. Industrial Marketing Management 40, 4, $581-592$.

Cull, R., et al. 2015. Government connections and financial constraints: evidence from a large representative sample of Chinese firms. Journal of Corporate Finance 32, 271-294.

Chandy, Rajesh K., and Gerard J. Tellis, 2000. The incumbent's curse? Incumbency, size, and radical product innovation. Journal of marketing 64, 3, 1-17.

Dooley, Lawrence, Breda Kenny, and Michael Cronin, 2015. Interorganizational innovation across geographic and cognitive boundaries: does firm size matter? R\&D Management 46.S1, 227-243.

Doney, Patricia M., and Joseph P. Cannon, 1997. An examination of the nature of trust in buyer-seller relationships. Journal of Marketing 61, 2, 35-51.

Damanpour, Fariborz,1992. Organizational size and innovation. Organization Studies, $13,3,375-402$.

Ettlie, John E., and Albert H. Rubenstein. 1987. Firm size and product innovation. Journal of Product Innovation Management 4, 2, 89-108.

Faccio, Mara. 2006. Politically connected firms. American Economic Review 96, 1, 369-386.

Faccio, M., Masulis, R. W., \& McConnell, J. 2006. Political connections and corporate bailouts. The Journal of Finance, 61(6), 2597-2635.

Faccio, Mara. 2010. Differences between politically connected and nonconnected firms: A cross-country analysis. Financial Management, 39, 3, 905-928.

Fan, Joseph PH, Tak Jun Wong, and Tianyu Zhang. 2007. Politically connected CEOs, corporate governance, and Post-IPO performance of China's newly partially 
privatized firms. Journal of Financial Economics, 84, 2, 330-357.

Golovko, Elena, and Giovanni Valentini. 2014. Selective learning-by-exporting: Firm size and product versus process innovation. Global Strategy Journal, 4, 3, 161-180.

Hitt, Michael A., et al. 1991. Effects of acquisitions on R\&D inputs and outputs. Academy of Management Journal, 34, 3, 693-706.

Hoffman, Lynn. 1992. Constructing the theoretical context. In McNamee, S., and Gergen, K. J., Therapy as Social Construction 7-24. Thousand Oaks, CA: Sage.

Jackowicz, K., Kozłowski, Ł., \& Mielcarz, P. 2014. Political connections and operational performance of non-financial firms: New evidence from Poland. Emerging Markets Review, 20, 109-135.

Jiao, Hao, Chun Kwong Koo, and Yu Cui, 2015. Legal environment, government effectiveness and firms' innovation in China: Examining the moderating influence of government ownership, Technological Forecasting and Social Change, 96, 15-24.

Johnson, S., and Mitton, T., 2003. Cronyism and capital controls: evidence from Malaysia. Journal of Financial Economics 67,2, 351-382

Khwaja, Asim Ijaz, and A. Mian. 2005.Do Lenders Favor Politically Connected Firms? Rent Provision in an Emerging Financial Market. The Quarterly Journal of Economics ,120,4,1371-1411.

Li, Hongbin, et al. 2008. Political connections, financing and firm performance: Evidence from Chinese private firms. Journal of Development Economics, 87,2, 283-299.

Lin, Chen, et al., 2011. Managerial incentives, CEO characteristics and corporate innovation in China's private sector. Journal of Comparative Economics, 39, 2, 
176-190.

Lin, H., et al. 2014. Can political capital drive corporate green innovation? Lessons from China. Journal of Cleaner Production, 64, 63-72.

Luo, Yadong, 2008. The changing Chinese culture and business behavior: The perspective of intertwinement between guanxi and corruption. International Business Review, 17, 2, 188-193.

Makkai, T., \& Braithwaite, J. 1992. In and out of the revolving door: Making sense of regulatory capture. Journal of Public Policy, 12(01), 61-78.

Melitz, M. J. 2005. When and how should infant industries be protected. Journal of International Economics, 66(1), 177-196.

Neter, John, William Wasserman, and Michael H. Kutner. 1990. Applied Statistical Models. Boca Raton, FL: CRC Lewis Publishers.

Prajogo, Daniel I., Christopher M. McDermott, and Margaret A. McDermott, 2013. Innovation orientations and their effects on business performance: Contrasting small- and medium-sized service firms. R\&D Management, 43, 5, 486-500.

Peng, Mike W., and Yadong Luo. 2000. Managerial ties and firm performance in a transition economy: The nature of a micro-macro link. Academy of Management Journal, 43, 3, 486-501.

Penrose, Edith Tilton. 1959. The Theory of the Growth of the Firm. London: Basil Blackwell.

Qian Y. 2007. Do national patent laws stimulate domestic innovation in a global patenting environment? A cross-country analysis of pharmaceutical patent protection, 1978-2002. The Review of Economics and Statistics,89,3: 436-453.

Royston, Patrick, and Willi Sauerbrei. 2008. Multivariable Model-Building: A Pragmatic Approach to Regression Analysis Based on Fractional Polynomials for 
Modelling Continuous Variables. Chichester: John Wiley \& Sons.

Saure, P. 2007. Revisiting the Infant Industry Argument. Journal of Development Economics, 84(1), 104-117.

Salant, D. J. 1995. Behind the revolving door: a new view of public utility regulation. The Rand journal of economics, 362-377.

Shi, Yidan, and Pengyu Zhu. 2014. The impact of organizational ageing and political connection on organization technology innovation: an empirical study of IT industry and pharmaceutical industry in China. Asian Journal of Technology Innovation, 22, 2, 234-251.

Sethi, Rajesh, Daniel C. Smith, and C. Whan Park. 2001. Cross-functional product development teams, creativity, and the innovativeness of new consumer products. Journal of Marketing Research, 38, 1, 73-85.

Shleifer, Andrei, and Robert W. Vishny. 1994. Politicians and firms. Quarterly Journal of Economics, 109, 995-1025.

Song, M., Ai, H., \& Li, X. 2015. Political connections, financing constraints, and the optimization of innovation efficiency among China's private enterprises. Technological Forecasting and Social Change, 92, 290-299.

Shu, C., Page, A. L., Gao, S., \& Jiang, X. 2012. Managerial ties and firm innovation: is knowledge creation a missing link?. Journal of Product Innovation Management, 29(1), 125-143.

Tsai, Kuen-Hung, Ming-Hung Hsieh, and Erik Jan Hultink, 2011. External technology acquisition and product innovativeness: The moderating roles of R\&D investment and configurational context. Journal of Engineering and Technology Management, 28, 3, 184-200.

Walder, Andrew G. 2002. Markets and income inequality in rural China: Political 
advantage in an expanding economy. American Sociological Review, 67, 231-253.

Wakasugi, Ryuhei, and Fumihiko Koyata. 1997. R\&D, firm size and innovation outputs: Are Japanese firms efficient in product development? Journal of Product Innovation Management, 14, 5, 383-392.

Wang, Cheng Lu, and Henry FL Chung. 2013. The moderating role of managerial ties in market orientation and innovation: An Asian perspective. Journal of Business Research, 66, 12, 2431-2437.

Wernerfelt, Birger. 1984. A resource-based view of the firm. Strategic Management Journal, 5, 2, 171-180.

$\mathrm{Wu}$, Jie, 2011. Asymmetric roles of business ties and political ties in product innovation, Journal of Business Research, 64, 11, 1151-1156.

Wöhrl, R., Stefan Hüsig, and Michael Dowling. 2009. The interaction of R\&D intensity and firm age: Empirical evidence from technology-based growth companies in the German “Neuer Markt”. Journal of High Technology Management Research, 20, $1,19-30$.

Xin, Katherine K., and Jone L. Pearce. 1996. Guanxi: Connections as substitutes for formal institutional support. Academy of management journal, 39, 6, 1641-1658.

Yen, Ju-Fang, et al. 2014. Can political and business connections alleviate financial constraints? Applied Economics Letters, 21, 8, 550-555.

Yoo, Jae Wook, and Richard Reed, 2015. The effects of top management team external ties and board composition on the strategic choice of late movers. Long Range Planning, 48, 1, 23-34. 
Yu, Minggui and Pan Hongbo. 2008. The Relationship between Politics, Institutional Environments and Private Enterprises' Access to Bank Loans. Management World, 8,004

Zhou, Wubiao. 2013. Political connections and entrepreneurial investment: Evidence from China's transition economy. Journal of Business Venturing, 28, 2, 299-315.

Zhou, Wubiao. 2014. Regional institutional development, political connections, and entrepreneurial performance in China's transition economy. Small Business Economics, 43, 1, 161-181. 
Table 1. Industries in the sample

\begin{tabular}{|c|c|c|}
\hline Industry & Percentage & Average R\&D intensity \\
\hline Industrial manufacturing & $35.433 \%$ & $3.859 \%$ \\
\hline Agriculture and forestry & $1.684 \%$ & $1.370 \%$ \\
\hline Mining & $2.898 \%$ & $2.320 \%$ \\
\hline Electricity, heat and gas & $3.454 \%$ & $0.062 \%$ \\
\hline $\begin{array}{c}\text { Transport, warehousing } \\
\text { and postal services }\end{array}$ & $3.454 \%$ & $0.720 \%$ \\
\hline Information technology & $2.978 \%$ & $12.780 \%$ \\
\hline $\begin{array}{c}\text { Software and information } \\
\text { technology service }\end{array}$ & $38.449 \%$ & $3.420 \%$ \\
\hline $\begin{array}{c}\text { Water conservancy and } \\
\text { environmental } \\
\text { management }\end{array}$ & $1.191 \%$ & $4.030 \%$ \\
\hline $\begin{array}{c}\text { Culture, sports and } \\
\text { entertainment }\end{array}$ & $1.311 \%$ & $2.456 \%$ \\
\hline Health and social work & $2.143 \%$ & $4.165 \%$ \\
\hline $\begin{array}{c}\text { Scientific research and } \\
\text { technical services }\end{array}$ & $0.794 \%$ & $1.812 \%$ \\
\hline Wholesale and retail trade & $6.074 \%$ & \\
\hline
\end{tabular}

Note: Percentage represents the share of firms from the corresponding industry to the total number of firms; Average R\&D intensity represents the average R\&D spending (investment) of firms in each industry as a share of income.

Table 2. Descriptive Statistics $(\mathrm{N}=\mathbf{2 , 5 8 7})$

\begin{tabular}{|c|c|c|c|}
\hline Variable & Mean & St. Dev. & Median \\
\hline 1.AntiCorrup & 22.207 & 6.381 & 23.02 \\
\hline 2.GovSupport & 0.019 & 0.084 & 0.007 \\
\hline 3.R\&Dinput & 0.034 & 0.046 & 0.029 \\
\hline 4.Income & 937334.2 & 7728463 & 119314.6 \\
\hline 5.Topshare & 32.438 & 18.662 & 31.73 \\
\hline 6.Firmsize & 6089.929 & 24994.85 & 1683 \\
\hline 7.PoliticalConnection & 8.647 & 9.520 & 1 \\
\hline 8.Fixedassets & 311634.6 & 2050725 & 37851.37 \\
\hline $9 . R O A$ & 7.717 & 10.807 & 6.262 \\
\hline 10.Firmage & 18.243 & 5.044 & 18 \\
\hline
\end{tabular}

Note: We calculate the "political connections" for a firm based on the total sum of all senior management team members' score on political connections. Each member's political connection score varies between 0 and 5 . 
Table 3. Correlations

\begin{tabular}{|c|c|c|c|c|c|c|c|c|c|c|}
\hline Variable & 1 & 2 & 3 & 4 & 5 & 6 & 7 & 8 & 9 & 10 \\
\hline 1.AntiCorrup & 1 & -0.002 & $-0.138 * * *$ & $-0.094 * * *$ & $-0.129 * * *$ & -0.002 & -0.001 & $-0.083 * * *$ & $-0.036^{*}$ & $0.105^{* * *}$ \\
\hline 2.GovSupport & -0.002 & 1 & $0.101 * * *$ & 0.020 & $0.012 * * *$ & 0.031 & 0.003 & 0.016 & $0.068 * * *$ & -0.012 \\
\hline 3.R\&Dinput & $-0.138 * * *$ & $0.101 * * *$ & 1 & $0.064 * * *$ & $0.098 * * *$ & $0.093 * * *$ & $0.217 * * *$ & $0.081 * * *$ & 0.029 & $-0.187 * * *$ \\
\hline 4.Income & $-0.094 * * *$ & 0.020 & $0.064 * * *$ & 1 & $0.133 * * *$ & $0.762 * * *$ & $0.132 * * *$ & $0.849 * * *$ & -0.022 & -0.001 \\
\hline 5.Topshare & -0.002 & $0.012 * * *$ & $0.098 * * *$ & $0.133 * * *$ & 1 & $0.146 * * *$ & $0.190 * * *$ & $0.155^{* * *}$ & $0.187 * * *$ & -0.023 \\
\hline 6.Firmsize & $-0.129 * * *$ & 0.031 & $0.093 * * *$ & $0.762 * * *$ & $0.146 * * *$ & 1 & $0.206^{* * *}$ & $0.722 * * *$ & $-0.044 * *$ & $-0.040 * *$ \\
\hline 7.PoliticalConnection & -0.001 & 0.003 & $0.217 * * *$ & $0.132 * * *$ & $0.190 * * *$ & $0.206 * * *$ & 1 & $0.179 * * *$ & $-0.083 * * *$ & $0.164 * * *$ \\
\hline 8.Fixedassets & $-0.083 * * *$ & 0.016 & $0.081 * * *$ & $0.849 * * *$ & $0.155 * * *$ & $0.722 * * *$ & $0.179 * * *$ & 1 & -0.028 & -0.010 \\
\hline 9.ROA & $-0.036^{*}$ & $0.068 * * *$ & 0.029 & -0.022 & $0.187 * * *$ & $-0.044 * *$ & $-0.083 * * *$ & -0.028 & 1 & $-0.134 * * *$ \\
\hline 10.Firmage & $0.105 * * *$ & -0.012 & $-0.187 * * *$ & -0.001 & -0.023 & $-0.040 * *$ & $0.164 * * *$ & -0.010 & $-0.134 * * *$ & 1 \\
\hline
\end{tabular}

Note: $* * * \mathrm{p}<0.01 ; * * \mathrm{p}<0.05 ; * \mathrm{p}<0.1$ 
Table 4. The score of political rank

\begin{tabular}{|c|c|}
\hline Score & Political rank \\
\hline 5 & $\begin{array}{c}\text { National-level leaders and } \\
\text { provincial-level officials }\end{array}$ \\
\hline 4 & Prefecture-department officials \\
\hline 3 & County level \\
\hline 2 & Township level \\
\hline 1 & Village level or below \\
\hline 0 & No political experience \\
\hline
\end{tabular}

Table 5. Results of regressions of model A

\begin{tabular}{|c|c|c|c|c|c|}
\hline $\begin{array}{r}\text { Type of } \\
\text { Model A }\end{array}$ & Equation & $\mathbf{R}^{2}$ & $\begin{array}{l}\text { Signif. } \\
\text { of } F\end{array}$ & Stand. coeff. b & RMSE \\
\hline Linear & $y=b_{0}+b_{1} X$ & 0.304 & 0.00 & $0.145^{* * *}$ & 0.886 \\
\hline Quadratic & $y=b_{0}+b_{1} X+b_{2} X^{2}$ & 0.303 & 0.00 & $\begin{array}{l}0.068 * *\left(\mathrm{~b}_{1}\right) \\
0.149 * * *\left(\mathrm{~b}_{2}\right)\end{array}$ & 0.884 \\
\hline Cubic & $y=b_{0}+b_{1} X+b_{2} X^{2}+b_{3}$ & 0.303 & 0.00 & $\begin{array}{l}0.080\left(b_{1}\right) \\
0.193\left(b_{2}\right) \\
-0.025\left(b_{3}\right)\end{array}$ & 0.884 \\
\hline Inverted & $y=b_{0}+b_{1} / X$ & 0298 & 0.00 & $0.113 * * *\left(\left(b_{1}\right)\right.$ & 0.883 \\
\hline \multicolumn{6}{|c|}{ The dependent variable is $R \& D$ input } \\
\hline
\end{tabular}


Table 6. Results of regression analysis

\begin{tabular}{|c|c|c|c|c|c|c|c|}
\hline \multirow{3}{*}{ Variables } & \multicolumn{7}{|c|}{ OLS } \\
\hline & \multirow[t]{2}{*}{ Model 0} & \multicolumn{2}{|c|}{ Model 1} & \multicolumn{2}{|c|}{ Model 2} & \multicolumn{2}{|c|}{ Model 3} \\
\hline & & Model 1a & Model $1 b$ & Model 2a & Model $2 b$ & Model 3a & Model 3b \\
\hline (Constant) & $-.242 * * *$ & $-1.440 * *$ & $-0.104 * *$ & $-0.154 * * *$ & $0.116^{* *}$ & $-0.185 * * *$ & $-0.185 * * *$ \\
\hline \multicolumn{8}{|l|}{ Control variables } \\
\hline GovSupport & $-.171 * * *$ & $-.222 * * *$ & $-.228 * * *$ & $-.177 * * *$ & $-.179 * * *$ & $-0.177 * * *$ & $-0.177 * * *$ \\
\hline Income & $0.849 * * *$ & $0.640 * * *$ & $0.678 * * *$ & $0.857 * * *$ & $0.848 * * *$ & $0.856 * * *$ & $0.853 * * *$ \\
\hline Topshare & $0.007 * * *$ & $0.005 * * *$ & $.005^{* * *}$ & $0.005^{* * *}$ & $0.005^{* * *}$ & $0.006 * * *$ & $0.006 * * *$ \\
\hline Fixedassets & $-0.303 * * *$ & $-0.433^{* * *}$ & $-0.413 * * *$ & $-0.325 * * *$ & $-0.323 * * *$ & $-0.327 * * *$ & $-0.326 * * *$ \\
\hline$R O A$ & 0.002 & 0.012 & 0.009 & 0.008 & 0.011 & 0.009 & 0.008 \\
\hline \multicolumn{8}{|l|}{ Main effects } \\
\hline PoliticalConnection (PC) & & $0.090 * * *$ & $0.063 * * *$ & $0.290 * * *$ & $0.155^{* * *}$ & $0.125 * * *$ & $0.125 * * *$ \\
\hline Firmsize & & $0.516^{* * * *}$ & $0.768 * * *$ & & & & \\
\hline Firmage & & & & $-0.053 * * *$ & $-0.071 * * *$ & & \\
\hline AntiCorrup & & & & & & $-0.053 *$ & $-0.048 * *$ \\
\hline \multicolumn{8}{|l|}{ Interaction terms } \\
\hline$P C^{*}$ Firmsize & & & $-0.209 * * *$ & & & & \\
\hline$P C^{*}$ Firmage & & & & & $-0.129 * * *$ & & \\
\hline$P C^{*}$ AntiCorrup & & & & & & & $-0.026^{*}$ \\
\hline Number of Observations & 2587 & 2587 & 2587 & 2587 & 2587 & 2587 & 2587 \\
\hline$F$ & 180.370 & 181.743 & 164.818 & 139.256 & 129.160 & 138.055 & 121.545 \\
\hline$R^{2}$ & 0.289 & 0.365 & 0.373 & 0.306 & 0.318 & 0.305 & 0.305 \\
\hline $\operatorname{Adj} R^{2}$ & & $0.363 * * *$ & $0.371 * * *$ & $0.303 * * *$ & $0.316^{* * *}$ & $0.302 * * *$ & $0.303 *$ \\
\hline
\end{tabular}

Note: $* * * \mathrm{p}<0.01 ; * * \mathrm{p}<0.05 ; * \mathrm{p}<0.1$ 